\title{
Municipal Green Purchasing in Mexico: Policy Adoption and Implementation Success
}

\author{
Ana R. Leal ${ }^{1}$, David Perez-Castillo ${ }^{2}{ }^{\circledR}$, José Ernesto Amorós ${ }^{2,3}{ }^{-}$and Bryan W. Husted ${ }^{2, *}$ \\ 1 Management Department, School of Business, Universidad de Monterrey, Monterrey 66238, Mexico; \\ anarleal@udem.edu \\ 2 EGADE Business School, Tecnologico de Monterrey, San Pedro Garza García 66269, Mexico; \\ david.perez@tec.mx (D.P.-C.); amoros@tec.mx (J.E.A.) \\ 3 School of Business and Economics, Universidad del Desarrollo, Santiago 7610658, Chile \\ * Correspondence: bhusted@tec.mx
}

Received: 30 August 2020; Accepted: 2 October 2020; Published: 10 October 2020

\begin{abstract}
In this paper, we seek to determine what factors drive the adoption of green purchasing among municipalities in Mexico and the success of their implementation. Given the lack of research and theory in the area, this study is exploratory in nature. We applied the green purchasing survey developed by Arizona State University to all municipalities in Mexico with a population of 25,000 or more inhabitants. Using the least absolute shrinkage and selector operator method (LASSO), we reduced the set of measures, which we then employed in a logistic regression to predict whether the municipality would adopt a green purchasing policy. We found that complementary environmental practices, department rules, and city-wide contracts to reduce purchasing costs have a positive and significant effect on the propensity to adopt green purchasing policies, but the time for routine low-cost purchases has a negative effect on green purchasing policy adoption. Then, using two-stage least squares, we developed a model of the factors leading to successful implementation of green purchasing. We found that complementary environmental policies, environmental practices, environmental program knowledge, and city-wide contracts to reduce purchasing costs are positively and significantly related to successful implementation. However, department resources and the time for routine low-cost purchase are significant, but negatively related.
\end{abstract}

Keywords: green public purchasing; municipal procurement; LASSO; Mexico

\section{Introduction}

Despite growing interest in green procurement in general [1,2], and municipal green purchasing policies in particular [3-5], little research has explained why cities adopt such policies nor the factors related to their successful implementation. The current literature is replete with studies about sustainability in local government [6-8], and some studies have focused specifically on green public procurement [9], but very little on green municipal procurement, although there are a few exceptions [10]. Even with a few studies on green municipal procurement, the literature has largely focused on sustainable purchasing among cities in the advanced industrial economies with little thought to the drivers of the adoption of such practices nor their success, especially in emerging economies $[3,4,10]$. Given the significant portion of gross domestic product (GDP) comprised by government spending, including municipal spending, green municipal procurement represents a critical leverage point to foster transition to an environmentally sustainable economy [11-13], warranting further attention.

In this paper, we ask: Why do cities in emerging economies adopt sustainable purchasing policies and what contributes to their successful implementation? Given that there is little theory to guide the 
answers to these questions, we answer this question by undertaking an exploratory study using LASSO (least absolute shrinkage and selector operator) to build a model of the drivers of green procurement in Mexican municipalities and the factors related to their successful implementation. Our data are obtained through a survey of all Mexican municipalities with a population over 25,000 people.

Mexico provides an especially favorable setting for this study, where government procurement at all levels amounts to $\$ 193.7$ billion USD of goods and services annually, amounting to approximately 23.5 percent of Mexico's country-level GDP [14] compared to a range of $8 \%$ to $25 \%$ of the GDP in other OECD countries [15]. Purchased items include vehicle fleets, construction materials, chemicals, electronics, and office materials, all of which contribute to global climate change and other environmental concerns throughout the lifecycle of these products. Hence, increasing green purchasing practices among municipalities points to a significant way to improve environmental and social sustainability within Mexico.

In order to address the environmental impacts associated with government purchasing, some municipalities have implemented green purchasing policies, which refer to the set of activities undertaken by an organization to implement purchasing that reduces negative effects on the environment [6]. Governments that practice green purchasing can reduce their environmental harm significantly [3]. By purchasing green products, municipalities can reduce energy-related carbon emissions, water, solid waste, and a host of other activities, while increasing internal efficiencies (e.g., reduced energy use) that lead to cost savings [4]. Since green products are often designed with enhanced durability features, green purchasing policies have the potential to reduce consumption, while creating significant market incentives for public and private organizations to reconsider their production processes, incorporate environmental principles into their daily business routines, and thereby reduce their environmental impacts.

In addition, green purchasing policies can expand the production of green products and services and stimulate the development of markets for products and services with environmentally friendly attributes by increasing demand. Our research shows that 65 percent of department heads indicate that current suppliers offer at least some environmentally friendly products. By increasing demand, municipal green purchasing has the potential to create spillover effects that extend up the supply chain and around the globe, leading to significant environmental improvements [10].

Currently, Mexico has some initiatives that promote public policies encouraging green purchasing, starting at the end of the 1990s due to international agreements [16]. The German Corporation for International Cooperation (GIZ), together with federal and local governments, has promoted public policies for green purchasing since 2014 [17]. Mexico City has taken significant leadership by publishing guidelines for green purchasing [18] and other pilot programs have been implemented in three municipalities [19]. Even though the Mexican government is voluntarily participating in sustainability practices [20] and Green Public Procurement (GPP) is mentioned in the last Annual Report of the President [21], twenty years have passed since the first efforts promoting GPP practices began, and the quality of green purchasing in municipalities is still low.

While there is some national and local legislation relevant to green purchasing in Mexico, there is no public policy to support the comprehensive adoption of green purchasing practices by the municipalities or states. Public procurement is subject to legislation in environmental policies, transparency, and other general policies. In 2016, a study of public policies found that sustainability criteria occur in only $12 \%$ of 49 legal policies that determine public purchasing in Mexico [17].

Although the adoption of public policies for green purchasing has made some progress, many municipalities have failed to implement them fully, suggesting that there are still significant barriers to effective green purchasing. There exists a lack of information on green alternatives, insufficient metrics to evaluate the sustainability of one product compared with another, and local regulations that force local governments to buy the cheapest option rather than the best option for society or the environment. 
The purpose of this study is to develop a model to predict the adoption of a municipal green purchasing policy and the success or failure of its implementation. We develop a model of green purchasing policy adoption and implementation by using the municipal green purchasing survey developed by Arizona State University [22], which allows us to incorporate neglected, but complementary sustainability and purchasing measures into our model [9], specifically complementary environmental and purchasing policies and practices, purchasing criteria, information access, leadership, employees and resources, vendor roles, and an innovation culture. Inclusion of these measures is important given the potentially significant effects they can have on the predictive accuracy of adoption models [23]. Developing an accurate predictive model that incorporates these measures is particularly important in evaluating the potentially unintended consequences of policy interventions, such as the conflicts between the priorities of the purchasing process, the lack of clear organizational guidelines, the slow and inefficient dissemination of GPP knowledge [15].

In order to develop this model, we use LASSO [24], which assists variable selection for developing predictive models. Such a model would support decisions by municipal authorities, policy-makers, municipal purchasing agents, and industry vendors alike. It balances model complexity with predictive performance. LASSO provides a way to identify important factors that relate to municipal behavior without relying on the researcher. By developing parsimonious models, LASSO also has the advantage that it requires less data and thus its models are easier to implement in places where data can be more difficult to obtain, such as in Mexico.

\section{Literature Review}

There are related concepts around the orientation of purchases towards products and services that are better for the planet, such as sustainable procurement [25], green public procurement [26], circular public procurement [23], eco-procurement [27], and environmentally preferred purchasing [28]. The last two concepts are also used in industry. Each of these terms deal with the same phenomenon, but there are slight inconsistencies among them.

Sustainable Procurement (SP) was defined in 2006 by the United Kingdom as "using procurement to support wider social, economic, and environmental objectives, in ways that offer real long-term benefits" [29]. Green Public Procurement (GPP) has been defined as "a purchasing process where the public authority strives to procure goods, services and works with less environmental impact, based on life cycle costs, compared to the non-green alternative that would otherwise be procured" [30]. Environmentally Preferable Purchasing (EPP) attempts "to address environmental challenges by taking advantage of government's vast purchasing power to create strong markets for environmentally friendly products and services" [31]. Circular Public Procurement (CPP) was defined recently by the European Union as "the process by which public authorities purchase works, goods or services that seek to contribute to closed energy and material loops within supply chains, whilst minimizing, and in the best case avoiding, negative environmental impacts and waste creation across their whole life-cycle" [32]. Despite the somewhat different orientations of these concepts, they generally refer to the selection of products and services whose environmental impacts are not harmful or the least harmful to the environment [33] and have the purpose of redirecting public policy toward a greater concern with sustainability. In addition, although these definitions reflect increasing interest in academic research, green public procurement is still in its infancy as a policy tool [23].

Most of the extant research on GPP has been conducted in developed countries such as Sweden, United Kingdom, Spain, The Netherlands, USA, Australia, Norway, Denmark, Germany, and Canada [15]. In terms of developing countries, apart from Latin America, there are studies in Africa [34], Ghana [35], India [36], Pakistan [37], South Africa [38], and Thailand [39]; however, most of them have been performed in China [40-47] and Nigeria [48-50].

Looking at research in Latin American, we found only five articles regarding GPP, all of them from Brazil. In 2015, Kleine and Brightwell [51] reported an analysis of the Brazilian school meals policy, which supports organic farms and provides meals to 43 million Brazilian children, showing the 
potential that public purchases have to stimulate sustainable agriculture. Three articles investigated key factors hindering GPP [15,52,53]. Finally, Novaes das Virgens, Andrade, and Hidalgo [54] analyzed the carbon footprint of public agencies, finding that GPP can be used to reduce up to 83 percent of the $\mathrm{CO}_{2}$ emissions generated by the government.

Considering this literature, the elements to implement GPP can be divided into four key actors, key drivers, barriers, and performance factors. First, key actors include government regulatory entities, procurement and environmental professionals, politicians, firms, the media, and civil society organizations [49]. Second, key drivers of GPP include personnel skills, green consciousness, clarity and specificity of policies, and environmentally friendly products/vendors information [45]. Third, the barriers to adoption of GPP can be grouped by institutional aspects (including culture, the lack of a relevant legal framework, lack of political will, lack of training and employee competences, stakeholder pressures, and the lack of long-term planning), issues related to the improvement of informational mechanisms (poor monitoring and inspection systems, inadequate policy measures, limited knowledge about the social and environmental impacts), the ability to make decisions in public managers (limited capacity of stakeholders, budget constraints, and lack of top management support), and market conditions and perceptions (unavailability of green products, the relative higher costs/prices of the sustainable options, the perception that sustainable items can restrict competition) $[15,35,37,48,52,53]$.

Finally, factors that have been relevant to predict GPP performance include knowledge of the regulatory requirements [42], information about different responsibilities in government departments and experience in developed countries; as well as the pressures, such as regulations, rewards, incentives, the relationship with non-governmental stakeholders [47], ethics [55], and the maturity of the program [41]. Interestingly, Wang et al. [46], studying contracts in a municipality in China, found that price and time efficiency are negatively associated with GPP and intellectual efficiency is negatively associated with the size of the procurement. Finally, we observed articles that compare the implementation of GPP between developed and developing countries based on consumption and production [56], institutional pressures and citizens' attitude towards sustainability [20], and the relevance of integrated e-procurement system towards effective SPP monitoring and evaluation [57].

For Mexico, we found only one article related to GPP among municipalities in Mexico. Pichardo Pagaza [58] analyzed the different services that municipal governments offer (i.e., drinking water, domestic drainage, waste disposal, wastewater treatment, hygiene and cleanliness of market places, and others) and discussed how they could promote a better environment and have a positive impact on the community's quality of life. However, a structured proposal that could contribute to GPP was not presented. Hence, to the best of the authors' knowledge, the present paper is the first study to analyze the adoption of GPP in Mexican municipalities.

\section{Methods}

\subsection{Research Design and Sample}

To achieve our research objectives, we conducted a national survey of municipalities in Mexico. Mexico is divided into 31 states and Mexico City. Each of the states is then divided into municipios, which we translate as municipalities, except for Mexico City, which is divided into alcaldias, which are administrative districts within Mexico City. There are 2464 municipalities and 16 administrative districts for Mexico City. A list of municipalities and administrative districts was obtained from the National Institute of Statistics, Geography, and Information (INEGI) based on the 2010 Census [59]. We surveyed all municipalities and administrative districts in Mexico with a population of 25,000 or more. This cutoff was based on the advice of experts, who stated that it would be very unlikely that municipalities with fewer people would have green purchasing policies. There were 769 municipalities or administrative districts with a population greater than or equal to 25,000 .

Because the project is focused on the implementation of organizational level purchasing and green purchasing policies, we surveyed municipal managers whose operations were (a) related to 
purchasing; (b) related to environmental management; or (c) significantly affected by purchasing. We surveyed directors within the following departments to obtain a representative view of green purchasing implementation: procurement, finance, management, environment, and public works.

There is no comprehensive directory with information about the municipalities. In order to obtain contact information, we began with the municipalities that had 25,000 or more residents. Using Google, we searched for the municipality's official webpage or from the website of the corresponding state government. Once a municipality webpage was found, we identified the relevant municipality departments with contact information. If the department director's contact information was available, we recorded the director's name, email address, phone number, and mailing address. If the director's information was not available, we made calls to the municipality to identify the person most appropriate to answer our survey. The questionnaire was applied online with telephone assistance from Berumen $y$ Asociados-an external survey vendor.

Response Rate, Representativeness, Common-Method Variance, and Non-Response Bias

A total of 769 municipalities met the criteria for inclusion, however we did not receive an answer from every municipality. In $14 \%$ of the municipalities, the department director was not available; for $30 \%$, no one ever answered the telephone; and $11 \%$ of municipalities refused to provide an answer. We attempted to obtain two responses from every municipality; however, we only obtained responses from 461 department directors in 347 municipalities. In other words, we were only able to obtain two responses for one-third of the municipalities. Where we had two responses from a given municipality, we averaged the responses for that municipality. The response rate at the municipality level was 45.12 percent $(n=769)$. Of the 461 department directors who responded to our survey, $21 \%$ were in purchasing departments, $29 \%$ in administration or comptroller departments, $3 \%$ were municipality managers (equivalent to city managers), $45 \%$ were in the environmental department, $1 \%$ each in the public works and maintenance departments.

To detect common-method variance bias, CMV, we used a Harman's single-factor test [60]. Following this procedure, we introduced all the scale items into an exploratory factorial analysis (maximum likelihood) and examined the unrotated factor solution to obtain the number of components with eigenvalues greater than 1 that explained the aggregate variance. The first factor accumulated $13 \%$ of the covariance between the items, and only with five factors did we obtain $55 \%$ of covariance. These results suggest that common method bias was not a problem in this survey [61].

For non-response bias we performed a series of two-sample t-tests with equal variances, comparing the early respondents with the late respondents. For the dependent variable, Green Policy Adoption, which was binary, we used a test of proportion. From the total set of variables, we did not find statistically significant differences between the mean (and proportion for binary variable) responses of these two groups of respondents. We found no difference in the responses between early and late responders, suggesting that non-response bias was not significant because late responders have been found to be equivalent to non-responders [62].

\subsection{Survey Instrument and Measures}

We developed the survey instrument based on a green municipal procurement instrument applied initially in the United States (U.S.) [6,22] and later in Japan [63]. The instrument was translated and adapted so that it could be applied in the Mexican context. Hence, there were some variations from the original U.S. instrument. We finalized the survey instrument in August 2019. The final survey contained 38 questions, including personal information, that required approximately $15 \mathrm{~min}$ to complete.

\subsubsection{Dependent Variables}

The instrument analyzed two dependent variables: green policy adoption and the success of green policy implementation. 


\section{Green Policy Adoption}

Consistent with the previous U.S. and Japan studies [6,63], we asked, "To the best of your knowledge, has your municipality implemented a formal policy pertaining to the following purchasing issues?" Department directors were provided with a list of policies, one of which was "Environmentally friendly purchasing", which was defined as follows: "environmentally friendly purchasing is the set of activities undertaken by an organization to implement purchasing that reduces negative effects on the environment". The (yes/no) response to this question was coded as a binary variable. Department directors who answered "Yes" to this question were coded as individuals working in municipalities that had a green purchasing policy in place. Those who answered "No" were coded as working in municipalities with no green purchasing policy.

\section{Green Policy Implementation Success}

At the end of the survey, a follow-up question was asked about implementation success: "We are interested in your overall assessment of the implementation of your municipality's environmentally friendly purchasing policy. How would you assess your municipality's overall implementation of this policy?" Respondents answered with an 11-point Likert scale, with 5 being "Very successful", 0 being "Neither successful nor unsuccessful", and -5 being "Very unsuccessful".

This measure of success is perceptual and was used for several reasons. First, municipalities' green purchasing policies are extremely diverse. They vary based on their degree of formalization, scope, maturity, and other factors. Determining actual implementation success would require using a benchmarking tool that would have to be applicable to all settings. Additionally, many department directors reported that their municipalities' green purchasing policies were unsuccessful. We anticipated that asking directors within these municipalities a series of questions that would not be applicable to them would lead to survey fatigue and nonresponse. Measuring perceptual success attempts to balance these survey design concerns.

\subsubsection{Independent Variables}

Based on the survey of U.S. cities, the instrument applied in Mexico addressed the following issues: local government purchasing activities, local government environmental sustainability policies/practices, department-level policies/practices, department structure and culture, and professional/personal information. Within these broader areas, questions covered topics including: the structure of purchasing decisions in a municipality, municipal-level purchasing policies and practices, department-level purchasing policies and practices, information on sustainable products, information on vendor relationships, influence of external groups (e.g., citizens, higher-levels of government). A complete list of the specific items as they related to these issues is included in Appendix A.

We generated the constructs for the independent variables by means of a principal component factor analysis (PCA) and a correspondence analysis (CA). PCA analysis creates a composite variable by capturing the information contained in larger sets of items and represents them on a smaller set of dimensions, referred to as principal components, which are a weighted sum of the original items. For PCA, we initially grouped items based on a common construct, as indicated in the original survey instrument. In the case of indexes based on binary variables, CA was used, which is an extension of PCA used in the case of binary variables [64]. The constructed variables were as follows.

Environmental Policies. This variable was constructed with 10 items with binary answers (yes/no) where we asked if environmental policies are present in the city. The environmental policies that were asked about were the sustainability policy, existence of a sustainability director, existence of a sustainability committee, energy and water conservation policy, green building policy, greenhouse gas emissions policy, recycling policy, climate change adaptation policy, and public consultations about sustainability. 
Environmental Practices. This variable was constructed with six items with binary answers (yes/no), where we asked if certain environmental practices were enacted in the city. Among those activities we included the following: tracking spending in environmental sustainability activities, setting goals for environmental performance, undergoing environmental training for all city employees, internal audits of environmental performance, publication of sustainability reports, and implementing an environmental management system.

Environmental Concerns. This variable was constructed with nine items that had five-point Likert-type answers that ranged from not important to very important. We asked how important different sets of environmental concerns were for the city. Within the environmental policies we asked about the following: energy conservation, water conservation, waste reduction, greenhouse gases reduction, recycling, air pollution reduction, biodiversity, mobility, and construction and urban planning.

Department Rules. This variable was constructed with two items with binary answers (yes/no), where we asked if they had many rules and procedures and if employees were reviewed because of such rules.

Department Resources. This variable was constructed with six items that had five-point Likert-type answers that ranged from strongly constrains to strongly facilitates. We asked the extent to which financial resources, human resources, employee attitudes, law and regulation, top management, and availability of information facilitates or constrains the implementation of a green purchase policy.

Department Innovation. This variable was constructed with four items that had four-point Likert-type answers that ranged from disagree to strongly agree. In this set of questions, we asked about the strength of the department's commitment to innovation, the working environment in the department, and employees' attitudes towards innovation.

Purchase Characteristics. This variable was constructed with four items that had a five-point Likert-type answers that ranged from not important to very important. In this set, among those questions some items we asked about were the purchase complexity, vendor identification, and how the purchase process review was.

Municipal Involvement. This variable was constructed with two items with binary answers (yes/no), where we asked how often the department interacts with either the municipality's executive manager or a municipal council member.

Environmental Program Knowledge. This variable was constructed with eight items that had five-point Likert-type answers that ranged from do not know to belong to a given program. We asked about national and international programs that are related to sustainable development.

Stakeholder Influence. This variable was constructed with ten items that had five-point Likert-type answers that ranged from not influential to highly influential. In this set of questions, we asked how influential different stakeholders were for the purchase decision.

Information Availability. This variable was constructed with six items with binary answers (yes/no), where we asked if the department has used a given source of information.

Department Environmental Concern. This variable was constructed with six items with five-point Likert-type answers that ranged from not important to very important. In this set of questions we asked how important different environmental concerns are for the department.

Citywide Contracting. This was a binary variable (yes/no) where respondents were asked if the department implements citywide contracting to reduce purchasing costs.

E-Procurement System. This was a binary variable (yes/no) where respondents were asked if the department had implemented an electronic procurement system.

Financial Strength. This was a five-point Likert-type variable where respondents were asked how strong the financial strength of the city was. The answers ranged from very weak to very strong.

Time for Routine Low-Cost Purchases. This variable was expressed in weeks and it showed the amount of time that is usually required between the request for a routine low-cost purchase and its approval. 
Time for Technical High-Cost Purchases. This variable was expressed in weeks and it shows the amount of time that is usually required between the request for a technical high cost purchase and its approval.

Top Management Decision Locus. This was a five-point Likert-type categorical variable where respondents were asked to what extent they agree with the assertion that top management is responsible of the implementation of sustainable policies.

Mid-Level Decision Locus. This was a five-point Likert-type variable where respondents were asked to what extent they agree with the assertion that mid-level management is responsible for the implementation of sustainable policies.

Staff Decision Locus. This was a five-point Likert-type variable where respondents were asked to what extent they agree with the assertion that staff are responsible for the implementation of sustainable policies.

\subsubsection{Control Variables}

As control variables, we included the total population, percentage of people with higher education (as a proxy of human capital), and municipal GDP per capita (as a proxy of degree of economic development. These data were gathered from INEGI [59].

\subsection{Empirical Analyses}

\subsubsection{Measurement Model. DESCRIPTIVE Statistics and Bivariate Correlations}

In order to assess the reliability and validity of the constructs, a measurement model was constructed using structural equation modeling. The model fit had a root mean squared error of approximation (RMSEA) of 0.5, which is acceptable given that it is less than the cutoff of 0.8 . We examined the reliability of the constructs by calculating Cronbach's alpha [65], which exceeded 0.7 in all cases, demonstrating adequate reliability. In terms of construct validity, we assessed the convergent validity by determining the average variance extracted (AVE) and composite reliability for all the constructs. The usual cutoff for AVE to assess convergent validity is 0.5, but an AVE of 0.4 may be permissible if it is accompanied by composite reliability higher than $0.6[66,67]$. All the constructs met the cutoff criterion, except environmental practices, department rules, and department innovation. Given that our purpose was exploratory, rather than hypothesis-testing, concerns about complying with specific cutoffs should be alleviated.

\subsubsection{Analytical Method}

Our analyses were done in three stages. First, we identified the relevant variables using LASSO (least absolute shrinkage and selection operator). Second, we took the variables identified by LASSO and used them to predict the adoption or not of a green purchasing policy with a logistic regression model. Third, we used two-stage least squares in order to determine the effectiveness of the adoption of a green purchasing policy. We now explain each stage in greater detail.

We began our exploratory analysis using LASSO (least absolute shrinkage and selection operator), which is a method that selects variables so as to avoid overfitting by placing less weight on less important variables and not placing too much weight on any variable [24]. Hence, LASSO improves both prediction accuracy and interpretability of the model over alternative methods. LASSO makes the same model assumptions as ordinary least squares regression (OLS) [68].

Specifically, LASSO penalizes non-zero coefficients and the sum of their absolute parameter estimates. LASSO can achieve both accuracy and interpretability by forcing the sum of the absolute value of the regression coefficients to be less than a fixed value, which forces some coefficients to be set to zero. This requirement essentially removes these variables from the model, thus selecting a simpler model [69]. LASSO has the advantage that it provides good prediction accuracy by removing less important coefficients and reduces variance without substantially increasing bias. This is especially 
useful with a small sample size and a large number of independent variables, which was the case in this study. By discarding insignificant variables, LASSO helps make the model easier to interpret.

We then applied a logistic regression model, where the dependent variable was the adoption by the municipality of a green purchasing policy, using the independent variables identified previously by LASSO. Finally, we used two-stage least squares, 2SLS to determine the implementation success of the green purchasing policy. The first stage consisted of the logistic regression, which also calculated the probability of adoption for each of the municipalities. This probability was then incorporated into the second stage, where the dependent variable was implementation success.

\section{Results}

The LASSO procedure gave us an initial set of variables to perform a more simple and accurate logistic regression. Appendix B summarizes the LASSO procedure for reference. Tables 1 and 2 provide the descriptive statistics and correlations among these selected variables.

The first step of our analysis, the logistic regression, is shown in Table 3. This model used municipality green purchasing policy adoption as the dependent variable. As we commented previously, the LASSO procedure was used because it helps to identify a model with good prediction accuracy. Based on the LASSO variables, the logistic model had a pseudo-R2 $=0.23$ (Wald chi2 $=60.95$, Prob $>$ chi $2=0.00$ ) and correctly classified $78.46 \%$ of the cases. These results indicate that our model has a good fit. Additionally, we had a lower Akaike information criterion (278.46) and Bayesian information criterion (362.50) when we compared it with LASSO's most parsimonious models with fewer degrees of freedom and the minimum number of independent variables.

The results report odds ratios in addition to the logistic regression coefficients, because they are easier to interpret. When an odds ratio is equal to or greater than one, then the relationship is positive, because the odds are of adoption. When the odds ratio is less than one, then the relationship is negative, because the independent variable reduces the odds of adoption. We observed that environmental practices $(\beta=0.52, p=0.03)$, department rules $(\beta=0.63, p=0.03)$, and city-wide contracts to reduce purchasing costs $(\beta=1.21, p=0.03)$ had a positive and significant effect on the propensity to adopt green purchasing policy. The time for routine low-cost purchases $(\beta=-0.30, p=0.001)$ had a negative and significant effect on the propensity to adopt green purchasing policy. From our control variables, we only found a significant and positive effect for the municipal GDP per capita ( $\beta=1.80, p=0.08$ ).

The second stage used the 2SLS model to predict the successful implementation of the previous green purchasing policy. Table 4 displays these results.

From these results we can observe that environmental policies ( $\beta=0.33, p=0.05)$, environmental practices $(\beta=0.37, p=0.09)$, environmental program knowledge $(\beta=0.35, p=0.002)$, and using city-wide contracts to reduce purchasing $\operatorname{costs}(\beta=1.21, p=0.06)$ are positive and significant in the successful implementation of green purchasing policy. However, department resources $(\beta=-0.25$, $p=0.07)$ and the time for routine low-cost purchase $(\beta=-0.37, p=0.01)$ are negative and significant. We tested for multicollinearity in the regression results using the variance inflation factor (VIF). In all cases, VIF was less than 5.0, suggesting that multicollinearity was not a problem. 
Table 1. Descriptive statistics.

\begin{tabular}{|c|c|c|c|c|c|}
\hline & Variable & Mean & S.D. & Min & Max \\
\hline 1. & Green Purchase & 0.71 & 0.46 & 0.00 & 1.00 \\
\hline 2. & Successful green purchase policy & 8.35 & 2.07 & 1.00 & 11.00 \\
\hline 3. & Environmental policies & 2.98 & 1.00 & 1.04 & 4.17 \\
\hline 4. & Environmental practices & 3.23 & 0.86 & 1.36 & 4.30 \\
\hline 5. & Environmental concerns & 0.01 & 1.06 & -0.82 & 6.79 \\
\hline 6. & Department rules & -0.01 & 0.95 & -0.58 & 4.04 \\
\hline 7. & Department resources & 0.01 & 1.00 & -1.18 & 3.02 \\
\hline 8. & Department innovation & -0.08 & 0.76 & -1.79 & 2.87 \\
\hline 9. & Purchase characteristics & -0.05 & 0.88 & -1.01 & 3.15 \\
\hline 10. & Leader involvement & 0.07 & 1.03 & -1.18 & 1.36 \\
\hline 11. & Environmental program knowledge & 0.17 & 1.06 & -0.97 & 4.13 \\
\hline 12. & Stakeholder influence & -0.05 & 1.01 & -1.43 & 2.31 \\
\hline 13. & Information availability & -0.17 & 0.95 & -1.06 & 1.68 \\
\hline 14. & Department environmental concern & -0.14 & 0.75 & -0.96 & 2.94 \\
\hline 15. & Citywide contracting & 0.85 & 0.35 & 0.00 & 1.00 \\
\hline 16. & E-Procurement system & 0.61 & 0.49 & 0.00 & 1.00 \\
\hline 17. & Financial strength & 2.53 & 1.05 & 1.00 & 5.00 \\
\hline 18. & Time for routine low-cost purchase & 1.91 & 1.72 & 1.00 & 12.00 \\
\hline 19. & Time for technical high-cost purchase & 4.36 & 5.55 & 1.00 & 52.00 \\
\hline 20. & Top management decision locus & 1.86 & 0.73 & 1.00 & 4.00 \\
\hline 21. & Mid-level management decision locus & 2.05 & 0.80 & 1.00 & 5.00 \\
\hline 22. & Staff decision locus & 2.07 & 0.87 & 1.00 & 5.00 \\
\hline 23. & $\%$ Population with higher education & 0.07 & 0.05 & 0.00 & 0.43 \\
\hline 24. & Population logarithm & 11.12 & 0.85 & 9.32 & 14.03 \\
\hline 25. & GDP per capita & 0.10 & 0.24 & 0.01 & 2.16 \\
\hline
\end{tabular}


Table 2. Correlations.

\begin{tabular}{|c|c|c|c|c|c|c|c|c|c|c|c|c|c|c|c|c|c|c|c|c|c|c|c|c|c|}
\hline Variables & 1 & 2 & 3 & 4 & 5 & 6 & 7 & 8 & 9 & 10 & 11 & 12 & 13 & 14 & 15 & 16 & 17 & 18 & 19 & 20 & 21 & 22 & 23 & 24 & 25 \\
\hline 1 & 1.00 & & & & & & & & & & & & & & & & & & & & & & & & \\
\hline 2 & $0.16^{*}$ & 1.00 & & & & & & & & & & & & & & & & & & & & & & & \\
\hline 3 & $0.33^{*}$ & $0.23 *$ & 1.00 & & & & & & & & & & & & & & & & & & & & & & \\
\hline 4 & $0.33 *$ & $0.24 *$ & $0.60 *$ & 1.00 & & & & & & & & & & & & & & & & & & & & & \\
\hline 5 & $-0.23 *$ & -0.12 & $-0.20 *$ & -0.18 * & 1.00 & & & & & & & & & & & & & & & & & & & & \\
\hline 6 & $0.14^{*}$ & 0.00 & 0.04 & 0.02 & -0.09 & 1.00 & & & & & & & & & & & & & & & & & & & \\
\hline 7 & $-0.16^{*}$ & -0.20 * & $-0.26^{*}$ & $-0.20^{*}$ & 0.05 & -0.01 & 1.00 & & & & & & & & & & & & & & & & & & \\
\hline 8 & $-0.15^{*}$ & $-0.13^{*}$ & $-0.16^{*}$ & $-0.22 *$ & $0.14^{*}$ & $-0.25^{*}$ & 0.11 & 1.00 & & & & & & & & & & & & & & & & & \\
\hline 9 & -0.21 * & $-0.14^{*}$ & -0.20 * & -0.23 * & $0.37^{*}$ & -0.07 & $0.18^{*}$ & 0.15 * & 1.00 & & & & & & & & & & & & & & & & \\
\hline 10 & 0.07 & $0.20 *$ & 0.05 & 0.07 & -0.26 * & 0.10 & -0.08 & -0.08 & $-0.18^{*}$ & 1.00 & & & & & & & & & & & & & & & \\
\hline 11 & $0.13^{*}$ & $0.17^{*}$ & $0.17^{*}$ & $0.24^{*}$ & -0.02 & 0.04 & -0.03 & -0.14 * & -0.09 & -0.03 & 1.00 & & & & & & & & & & & & & & \\
\hline 12 & $-0.15^{*}$ & -0.18 * & $-0.22 *$ & $-0.30^{*}$ & $0.26^{*}$ & -0.08 & $0.24 *$ & $0.17^{*}$ & $0.25 *$ & $-0.14^{*}$ & -0.09 & 1.00 & & & & & & & & & & & & & \\
\hline 13 & $-0.30^{*}$ & $-0.22 *$ & $-0.43^{*}$ & $-0.45^{*}$ & $0.20^{*}$ & -0.09 & $0.23 *$ & $0.17^{*}$ & $0.27^{*}$ & $-0.19^{*}$ & $-0.22 *$ & $0.28 *$ & 1.00 & & & & & & & & & & & & \\
\hline 14 & -0.16 * & -0.23 * & $-0.23 *$ & $-0.16^{*}$ & $0.45^{*}$ & -0.01 & 0.10 & $0.14^{*}$ & $0.32 *$ & $-0.19^{*}$ & -0.11 & $0.23 *$ & $0.25^{*}$ & 1.00 & & & & & & & & & & & \\
\hline 15 & $0.27 *$ & $0.18^{*}$ & $0.23 *$ & $0.19 *$ & $-0.19^{*}$ & 0.09 & -0.11 & -0.10 & $-0.14 *$ & 0.09 & 0.05 & -0.11 & $-0.27 *$ & -0.11 & 1.00 & & & & & & & & & & \\
\hline 16 & $0.17^{*}$ & -0.06 & 0.11 & 0.04 & -0.13 & 0.06 & -0.10 & -0.08 & -0.01 & -0.00 & 0.05 & -0.07 & -0.09 & -0.02 & $0.17^{*}$ & 1.00 & & & & & & & & & \\
\hline 17 & $-0.16^{*}$ & -0.25 * & $-0.24 *$ & $-0.28 *$ & $0.16^{*}$ & $-0.14 *$ & $0.29 *$ & $0.21 *$ & $0.21^{*}$ & $-0.17^{*}$ & -0.08 & $0.16^{*}$ & $0.28^{*}$ & $0.17 *$ & $-0.14 *$ & 0.02 & 1.00 & & & & & & & & \\
\hline 18 & -0.01 & $-0.13^{*}$ & 0.10 & 0.12 & -0.07 & 0.02 & 0.02 & 0.00 & -0.03 & -0.07 & 0.06 & -0.03 & -0.10 & -0.04 & 0.01 & 0.05 & -0.02 & 1.00 & & & & & & & \\
\hline 19 & $-0.16 *$ & -0.10 & $-0.19^{*}$ & -0.08 & -0.10 & -0.03 & $0.21 *$ & 0.11 & -0.00 & -0.05 & -0.11 & -0.03 & 0.03 & -0.09 & 0.01 & -0.02 & $0.20 *$ & $0.18^{*}$ & 1.00 & & & & & & \\
\hline 20 & $-0.14 *$ & -0.06 & $-0.15^{*}$ & $-0.16^{*}$ & $0.19^{*}$ & -0.08 & $0.21 *$ & $0.21 *$ & $0.17^{*}$ & $-0.13^{*}$ & -0.06 & $0.15 *$ & 0.08 & $0.28^{*}$ & -0.12 & -0.04 & $0.16 *$ & 0.03 & 0.10 & 1.00 & & & & & \\
\hline 21 & -0.10 & $-0.12 *$ & -0.14 * & -0.12 & 0.12 & -0.10 & 0.19 * & 0.17 * & $0.16^{*}$ & $-0.15 *$ & -0.03 & $0.22 *$ & 0.02 & $0.18 *$ & -0.10 & 0.00 & $0.17 *$ & 0.05 & $0.13 *$ & $0.57 *$ & 1.00 & & & & \\
\hline 22 & -0.21 * & -0.11 & $-0.13 *$ & -0.12 & $0.15^{*}$ & -0.14 * & $0.27 *$ & 0.20 * & 0.11 & -0.07 & -0.06 & $0.18 *$ & 0.09 & $0.18 *$ & -0.08 & $-0.19^{*}$ & 0.19 * & 0.01 & $0.17^{*}$ & $0.32 *$ & $0.44^{*}$ & 1.00 & & & \\
\hline 23 & 0.02 & -0.05 & 0.10 & 0.07 & 0.00 & 0.01 & -0.10 & 0.07 & -0.01 & -0.07 & -0.08 & 0.05 & 0.03 & 0.02 & 0.06 & $0.17^{*}$ & -0.02 & 0.04 & 0.03 & -0.07 & -0.02 & -0.08 & 1.00 & & \\
\hline 24 & 0.02 & -0.07 & 0.09 & 0.04 & -0.02 & -0.02 & -0.08 & 0.10 & 0.01 & -0.03 & -0.05 & 0.08 & 0.03 & 0.01 & 0.01 & $0.19^{*}$ & 0.03 & 0.12 & 0.06 & -0.05 & 0.01 & -0.00 & $0.58^{*}$ & 1.00 & \\
\hline 25 & 0.06 & -0.03 & -0.01 & -0.06 & -0.03 & -0.03 & -0.03 & 0.04 & 0.03 & -0.01 & -0.05 & 0.06 & 0.11 & 0.02 & -0.02 & -0.02 & 0.06 & 0.00 & 0.02 & -0.01 & 0.12 & -0.04 & $0.22 *$ & 0.06 & 1.00 \\
\hline
\end{tabular}


Table 3. Logistic Regression Model, Adoption of Green Purchasing Policy.

\begin{tabular}{|c|c|c|c|c|c|c|c|c|}
\hline Green Purchase & Odds Ratio & Coefficients & St.Err. & $t$-Value & $p$-Value & (95\% Conf & Interval) & Sig \\
\hline Environmental policies & 1.38 & 0.32 & 0.30 & 1.50 & 0.13 & 0.91 & 2.12 & \\
\hline Environmental practices & 1.68 & 0.52 & 0.41 & 2.14 & 0.03 & 1.05 & 2.71 & $* *$ \\
\hline Environmental concerns & 0.77 & -0.26 & 0.12 & -1.63 & 0.10 & 0.56 & 1.06 & \\
\hline Department rules & 1.93 & 0.66 & 0.57 & 2.23 & 0.03 & 1.08 & 3.43 & $* *$ \\
\hline Department resources & 0.83 & -0.19 & 0.17 & -0.93 & 0.35 & 0.55 & 1.24 & \\
\hline Department innovation & 0.83 & -0.19 & 0.20 & -0.80 & 0.42 & 0.52 & 1.32 & \\
\hline Purchase characteristics & 0.76 & -0.27 & 0.15 & -1.43 & 0.15 & 0.52 & 1.11 & \\
\hline Leader involvement & 0.83 & -0.19 & 0.15 & -1.06 & 0.29 & 0.58 & 1.18 & \\
\hline Environmental program knowledge & 1.13 & 0.12 & 0.20 & 0.69 & 0.49 & 0.80 & 1.60 & \\
\hline Stakeholder influence & 1.06 & 0.05 & 0.19 & 0.29 & 0.77 & 0.74 & 1.51 & \\
\hline Information availability & 1.04 & 0.04 & 0.26 & 0.15 & 0.88 & 0.63 & 1.71 & \\
\hline Department environmental concern & 1.12 & 0.11 & 0.31 & 0.41 & 0.68 & 0.65 & 1.92 & \\
\hline Citywide contracting & 3.37 & 1.21 & 1.64 & 2.49 & 0.01 & 1.30 & 8.76 & $* *$ \\
\hline E-Procurement system & 1.09 & 0.08 & 0.42 & 0.21 & 0.83 & 0.51 & 2.31 & \\
\hline Financial strength & 1.28 & 0.24 & 0.28 & 1.11 & 0.27 & 0.83 & 1.97 & \\
\hline Time for routine low-cost purchase & 0.74 & -0.30 & 0.07 & -3.29 & 0.00 & 0.62 & 0.89 & $* * *$ \\
\hline Time for high-cost purchase & 0.98 & -0.02 & 0.02 & -0.94 & 0.35 & 0.94 & 1.02 & \\
\hline Top management decision locus & 0.75 & -0.29 & 0.24 & -0.89 & 0.38 & 0.40 & 1.42 & \\
\hline Mid-level decision locus & 1.37 & 0.31 & 0.35 & 1.21 & 0.23 & 0.82 & 2.27 & \\
\hline Staff decision locus & 0.71 & -0.34 & 0.16 & -1.56 & 0.12 & 0.46 & 1.09 & \\
\hline$\%$ Population with higher education & 0.00 & -7.78 & 0.00 & -1.64 & 0.10 & 0.00 & 4.70 & \\
\hline Population logarithm & 1.55 & 0.44 & 0.47 & 1.44 & 0.15 & 0.85 & 2.81 & \\
\hline GDP per capita & 6.07 & 1.80 & 6.27 & 1.74 & 0.08 & 0.80 & 46.04 & * \\
\hline Constant & 0.00 & -6.41 & 0.01 & -1.94 & 0.05 & 0.00 & 1.06 & * \\
\hline Mean dependent var & \multicolumn{2}{|c|}{0.71} & \multicolumn{3}{|c|}{ SD dependent var } & \multicolumn{3}{|c|}{0.46} \\
\hline Pseudo r-squared & \multicolumn{2}{|c|}{0.22} & \multicolumn{3}{|c|}{ Number of obs. } & \multicolumn{3}{|c|}{246.00} \\
\hline Chi-square & \multicolumn{2}{|c|}{60.95} & \multicolumn{3}{|c|}{ Prob $>$ chi2 } & \multicolumn{3}{|c|}{0.00} \\
\hline Akaike crit. (AIC) & \multicolumn{2}{|c|}{278.47} & \multicolumn{3}{|c|}{ Bayesian crit. (BIC) } & \multicolumn{3}{|c|}{362.59} \\
\hline
\end{tabular}

$* * * p<0.01, * * p<0.05 * *<<0.1$ 
Table 4. Two-stage least squares, implementation success of the green purchasing policy.

\begin{tabular}{|c|c|c|c|c|c|c|c|}
\hline P20_long & Coef. & St.Err. & $t$-Value & $p$-Value & (95\% Conf & Interval) & Sig \\
\hline Green purchase & -1.39 & 1.72 & -0.81 & 0.42 & -4.77 & 1.99 & \\
\hline Environmental policies & 0.33 & 0.17 & 1.94 & 0.05 & 0.00 & 0.66 & * \\
\hline Environmental practices & 0.37 & 0.21 & 1.71 & 0.09 & -0.05 & 0.78 & * \\
\hline Environmental concerns & 0.01 & 0.15 & 0.03 & 0.97 & -0.30 & 0.31 & \\
\hline Department rules & 0.04 & 0.16 & 0.23 & 0.82 & -0.28 & 0.36 & \\
\hline Department resources & -0.25 & 0.14 & -1.82 & 0.07 & -0.51 & 0.02 & * \\
\hline Department innovation & -0.19 & 0.17 & -1.06 & 0.29 & -0.53 & 0.16 & \\
\hline Purchase characteristics & -0.05 & 0.17 & -0.27 & 0.79 & -0.38 & 0.29 & \\
\hline Leader involvement & 0.22 & 0.14 & 1.58 & 0.11 & -0.05 & 0.49 & \\
\hline Environmental program knowledge & 0.35 & 0.11 & 3.10 & 0.00 & 0.13 & 0.57 & $* * *$ \\
\hline Stakeholder influence & -0.19 & 0.14 & -1.42 & 0.16 & -0.46 & 0.08 & \\
\hline Information availability & 0.18 & 0.15 & 1.24 & 0.22 & -0.11 & 0.47 & \\
\hline Department environmental concern & -0.22 & 0.22 & -1.01 & 0.31 & -0.64 & 0.21 & \\
\hline Citywide contracting & 1.21 & 0.64 & 1.90 & 0.06 & -0.04 & 2.47 & * \\
\hline E-procurement system & -0.01 & 0.24 & -0.03 & 0.98 & -0.48 & 0.47 & \\
\hline Financial strength & 0.08 & 0.16 & 0.55 & 0.59 & -0.22 & 0.39 & \\
\hline Time for routine low-cost purchase & -0.37 & 0.13 & -2.84 & 0.01 & -0.63 & -0.12 & $* * *$ \\
\hline Time for technical high-cost purchase & 0.01 & 0.03 & 0.23 & 0.82 & -0.05 & 0.06 & \\
\hline Top management decision locus & 0.33 & 0.22 & 1.50 & 0.13 & -0.10 & 0.75 & \\
\hline Mid-level decision locus & -0.06 & 0.21 & -0.30 & 0.77 & -0.47 & 0.35 & \\
\hline Staff decision locus & -0.25 & 0.22 & -1.12 & 0.26 & -0.69 & 0.19 & \\
\hline Constant & 6.56 & 0.81 & 8.09 & 0.00 & 4.97 & 8.15 & $* * *$ \\
\hline Mean dependent var & \multicolumn{2}{|c|}{8.35} & \multicolumn{2}{|c|}{ SD dependent var } & \multicolumn{3}{|c|}{2.06} \\
\hline R-squared & \multicolumn{2}{|c|}{0.23} & \multicolumn{2}{|c|}{ Number of obs. } & \multicolumn{3}{|c|}{246.00} \\
\hline Chi-square & \multicolumn{2}{|c|}{127.59} & \multicolumn{2}{|c|}{ Prob > chi2 } & \multicolumn{3}{|c|}{0.00} \\
\hline
\end{tabular}




\section{Discussion}

Given the lack of a model of drivers of municipal green purchasing, we undertook an exploratory study to understand the drivers of green purchasing among Mexican municipalities. To do so we applied a survey of municipal green purchasing developed by researchers at Arizona State University to all Mexican municipalities with populations of over 25,000 inhabitants. Using LASSO, we were able to reduce the number of factors that would produce a stable model of municipal green purchasing, which we then tested using a logistic regression analysis to predict whether a municipality had green purchasing or not. We then used the results of the logistic regression in a two-stage least squares to determine the factors leading to the implementation success of the green purchasing policy.

To date there are very few studies of green purchasing at the municipal level, and none in Mexico. Given the pivotal role that green purchasing in the public sector could play in fostering sustainability, the study of the drivers of the adoption of green purchasing policies is critical to fostering suppliers of sustainable products and services, as well as disseminating sustainability practices more generally.

\subsection{Green Purchasing Policy Adoption}

Given the exploratory nature of this study, which has as its final purpose the construction of a model for adopting green purchasing policies, the results suggest several important contributions to the literature. In summary, the factors concerning the adoption of a green purchasing policy are related to both current purchasing policy and related environmental practices.

First, among the current purchasing policies, the most salient purchasing practice that seems to foster the adoption of green purchasing policy is the use of citywide purchase contracts to reduce costs. Such contracts seek to achieve economies of scale in purchasing by unifying municipal purchases in such purchase contracts [70]. So, municipalities that use purchase contracts to unify purchasing across the municipality to reduce costs are more likely to adopt green purchasing policies.

Another consideration related to current purchasing policy that fosters green purchasing adoption is the effectiveness of the local bureaucracy. Two contrasting findings bring this consideration into focus. As the number of weeks for routine low-cost purchases increases, it is less likely that a municipality will adopt green purchasing practices. This finding makes sense because it suggests that slower purchasing systems discourage green purchasing policies. However, this result contrasts with some surprising results for department rules. We asked whether the department had too many rules and procedures and whether employees in the department were constantly being monitored for rule violations. In this case, municipalities with more rules and rule enforcement were more likely to adopt a green purchasing policy. Thus, the existence of rules facilitates the adoption of green purchasing policy, but the increase in time to engage in routine purchases suggests that when rules or bureaucrats slow down the purchase decision, then green purchasing policy adoption is reduced. It appears that municipal authorities need to balance having sufficient rules and monitoring to guide purchase processes, but not so much that it begins to slow down the purchasing process.

This finding echoes calls in the literature to take a more nuanced approach to bureaucracy in order to understand when it is effective and when it is excessive or unduly burdensome [71,72]. So, bureaucratic rules and monitoring can be "enabling", but can become excessive and disabling by increasing the time to make purchases.

Another major factor that is vital to the adoption of green purchasing policy is the set of complementary environmental practices in the municipality. As the municipality engages in other green activities, it is more likely to adopt green purchasing policies. These activities include tracking spending on environmental sustainability activities, setting goals/targets for environmental performance, environmental training for all city employees, internal audits of environmental performance, publication of environmental sustainability reports, and environmental management systems. The existence of complementary environmental practices in areas not related to purchasing suggests that a municipality has a commitment to environmental sustainability, which provides a propitious context for deepening this commitment through the adoption of a green purchasing policy. 
The last major factor is the importance the department gives to other environmental concerns. Although the sign on this variable is negative, it is a Likert scale where " 1 " means very important and " 5 " means not at all important. This variable consists of such issues as energy and water conservation, waste reduction, greenhouse gases, recycling, air pollution reduction, biodiversity, mobility, and construction. The greater the importance of these related environmental concerns, the more likely that the municipality will adopt a green purchasing policy. So, clearly the green purchasing policy is seen as a component of an entire array of environmental concerns with which the municipality is involved and the purchasing policy is not an isolated policy.

\subsection{Green Purchasing Policy Implementation}

Our second model looked at the factors that lead to successful implementation of green purchasing policies. Five variables are significantly related to the success of implementation. Two of the variables that explain the adoption of a green purchasing policy also support successful implementation of the policy. The first is the existence of city-wide contracts to reduce purchasing costs. Again, the use of use contracts represents an efficient practice that not only enables the adoption of a green purchasing policy, but also its successful implementation.

On the other hand, to the extent that routine, low-cost purchases take more time, this variable, which reflects inefficiency and higher transaction costs, not only reduces the likelihood of adopting a green purchasing policy, but also reduces the success of its implementation. Taken together, these two practices represent a fundamental administrative infrastructure that is needed to support the adoption and successful implementation of a green purchasing policy.

A third variable that is related to successful implementation is the knowledge of the respondent with respect to other environmental programs, both in Mexico and around the world. The respondents who knew more about Mexican programs, such as Sustainable Public Contracts from the Civil Service Secretariat [73], the Mexico City program for sustainable purchasing [18], the environmental secretariat's Special Program for Sustainable Consumption and Production [74], and the Mexican Climate Change Law [75], as well as international programs, such as the Interamerican Network on Government Procurement (RICG) [76], Local Governments for Sustainability (ICLEI) [77], the Marrakech Task Force on Sustainable Public Procurement [78], and Global Lead City Network on Sustainable Procurement (GLCN) [79], were involved in more successful implementation of their green purchasing policy. This question helped determine to what extent the respondents knew about green procurement. Hence, in-depth knowledge about green purchasing appears to be very important in the successful implementation of such policies.

Fourth, the number of other environmental policies that exist in the municipality increases the likelihood of adopting environmental purchasing policies. Specifically, it includes the following: an environmental sustainability director, environmental sustainability committee, environmental sustainability policy, energy conservation policy, water conservation policy, green building policy, greenhouse gas emissions policy, recycling policy, climate change adaptation policy, and public consultation about sustainability. The findings show that as the number of environmental policies and practices increases, the success of the implementation of the green purchasing policy also increases. This result suggests that municipalities view environmental purchasing in the context of other environmental policies. When other such policies exist, then environmental purchasing will be implemented more successfully.

Finally, departmental resources are negative and significant. This result suggests that the lack thereof of certain resources acts as a constraint on the successful implementation of green purchasing policies. Such resources are needed for any kind of policy and thus it is not surprising that they also hobble the implementation of green purchasing where they are lacking. 


\subsection{Contributions to Practice}

The findings of this study also have practical implications for policy-makers and municipal administrators. Policy-makers need to understand that green purchasing does not stand alone and that it lies at the intersection of other efficient purchasing practices and environmental practices. There is a configuration of practices and policies that provide the backdrop for the adoption of green purchasing policies that must exist. For public administrators, the lesson is that green purchasing is adopted when it can be laid over efficient purchasing practices. The public administrator needs to have an array of complementary environmental practices and policies in place before adopting a green purchasing policy. Furthermore, for green purchasing to be implemented successfully, beyond the base level of bureaucratic efficiency, cities need to have sufficient resources of all types in order to implement these policies. Finally, environmental officials need to have deep knowledge of green purchasing practices for implementation to be successful.

\subsection{Limitations of the Study}

This study certainly had its limitations. The survey was long, and respondents may have suffered from survey fatigue. As a result, some respondents may not have carefully distinguished answers from one item to the next. The environmental practices variable was the only variable in the final models that did not meet the criteria for construct validity. Given the exploratory nature of the study, we believe that it was important to include this variable. Further work to develop a valid measure of environmental practices should be undertaken. In addition, this questionnaire was open to subjective responses and hence, other questionnaires or methods that incorporate more objective indicators should also be used. Qualitative research would also enrich this survey by investigating the processes by which decisions about green purchasing are made. Finally, the results of this survey are probably not applicable to other institutional contexts, but only to Mexico. Clearly further research is warranted.

\subsection{Future Research}

This study took the perspective of the municipality, but the next step requires going to the suppliers. To what extent does a municipal green purchasing policy stimulate green products and services inside and outside the municipality? What are the barriers that suppliers face in providing green products and services to municipalities? Does a green purchasing policy generate a demonstration effect on others so that it initiates a cultural change within the municipality among other organizations and its residents in general? These are fascinating avenues for future research that will help determine the extent that municipal green purchasing can be translated into greening the supply chain, and ultimately improving environmental quality for all.

Author Contributions: All authors contributed to the different underlying processes necessary for the development of this article. All four worked together to translate the original survey into Spanish and participate in the data collection. All authors worked together in the conceptualization of the paper's main ideas. B.W.H. led the drafting of the paper. D.P.-C. led in the development of the literature review. A.R.L. and J.E.A. led the data analyses, while all authors provided substantive feedback, comments, and direction in the development of the manuscript. All authors have read and agreed to the published version of the manuscript.

Funding: This research was funded by a grant from the Global Consortium for Sustainability Outcomes (\#001036).

Acknowledgments: We acknowledge essential support from Nicole Darnall and the team at Arizona State University. We also acknowledge administrative support from the Tecnologico de Monterrey.

Conflicts of Interest: The authors declare no conflict of interest. The funders had no role in the design of the study; in the collection, analyses, or interpretation of data; in the writing of the manuscript, or in the decision to publish the results.

\section{Appendix A. Questionnaire}

1. There are a variety of ways that cities conduct the purchasing of products and services. Please indicate the extent to which you agree with the following statements related to how 
purchasing is conducted in your city [Answer options: From Strongly agree (1) to Strongly disagree (5) and Don't know].
a. The finance department conducts all purchasing
b. Individual departments do all of their own purchasing
c. Separate departments cooperate to make purchases
d. Departments coordinate with higher level offices to make purchases (e.g., city manager's office)
e. The finance department provides support for department purchasing

2. To the best of your knowledge, has your city implemented the following purchasing activities? [Answer options: Yes, No, Don't know].
a. Citywide contracts to reduce purchasing costs
b. An e-procurement system

If 2. Please indicate whether your city has implemented the following elements in your e-procurement system [Answer options: Yes, No, Don't know].
c. Online bid process
d. E-procurement training for purchasing officers
e. Tracking of e-procurement purchases
f. Database of environmentally friendly products and services

3. To the best of your knowledge, has your city implemented a formal policy pertaining to any of the following purchasing issues [Answer options: Yes, No, Don't know].
a. Minority-owned business purchasing (e.g., indigenous groups)
b. Women-owned business purchasing
c. Environmentally sustainable purchasing
d. Local business purchasing
e. Small business purchasing

4. Please indicate whether the following environmental practices have been implemented or adopted throughout your city [Answer options: Yes, No, Don't know].
a. Tracking of spending on environmental sustainability activities
b. Setting goals and targets for environmental performance
c. Environmental training for all city employees
d. Internal audits of environmental performance
e. Publication of an environmental/sustainability report
f. Using an environmental management system
g. Other

5. To the best of your knowledge, does your city have any of the following? [Answer options: Yes, No, Don't know].
a. Citywide environmental sustainability director
b. Citywide environmental sustainability committee
c. Citywide environmental sustainability policy
d. Energy usage conservation policy
e. Water usage conservation policy
f. Green building policy
g. Greenhouse gas emissions policy 
h. Recycling policy

i. Citywide discussions about environmentally sustainable purchasing practices across units

6. Over the last five years, how important has each of the following federal or state government programs been in promoting environmental sustainability in your city? [Answer options: From Very important (1) to Not important (5) and Don't know].
a. Grants
b. Technical assistance (e.g., climate change policies)
c. Voluntary programs (e.g., Sustainable Development Goals)
d. Awards/recognition programs
e. Educational programs

7. For each type of purchase, identify every level of approval that is required for authorization. Check all levels that apply for each type of purchase: [Answer options: Routine, Low-Cost Purchases; Routine, High-Cost Purchases; Non-routine, High-Cost Purchases w/Technical Specifications; and Don't know].
a. Departmental
b. City Finance Office/Department
c. City Executive Manager (Mayor or City Manager)
d. City Council

8. For each type of purchase, check the box if the following is used in your department's purchasing process [Answer options: Routine, Low-Cost Purchases; Routine, High-Cost Purchases; Non-routine, High-Cost Purchases w/Technical Specifications; and Don't know].
a. Approved vendor list
b. Existing or prior contract
c. Bid process
d. Information system searches to find multiple options
e. Information on the environmental impact of products
f. Information on life cycle cost
g. Prior approval from unit budget/finance officer
h. Prior approval from higher unit budget officer
i. Ecolabels/certifications
j. Preferred green products/services list

9. For each type of purchase, please indicate how much time (in weeks) is typically required between a purchasing request being made by your department and the actual approval of that request [Answer options: number of weeks].
a. Routine, Low-Cost Purchases
b. Routine, High-Cost Purchases
c. Non-Routine High-Cost Purchases w/Technical Specifications

10. Departments may use a number of different information sources when making purchases. Please indicate whether each of the following information sources is available to your department when making purchasing decisions [Answer options: Yes, No, Don't know].
a. Information on the environmental impact of products
b. Product ecolabels/certifications
c. Green product/service list 

d. Minority business list
e. Small business list
f. Business in marginalized areas

11. There are many different criteria that may be considered in the purchase of a product or service. In thinking about your department's purchasing criteria, how important is each of the following characteristics of a product or service? [Answer options: From Very important (1) to Not important (5) and Don't know].
a. Purchase price
b. Execution of pre-existing contract agreements
c. Performance requirement
d. Buying from minority/women businesses
e. Buying from local businesses
f. Greenhouse gas emissions reductions
g. Environmental impact (e.g., water use, solid waste)
h. Life-cycle cost of the product
i. Maintaining vendor relationships

12. How important are technical specifications to your department when managing the following aspects of purchases [Answer options: From Very important (1) to Not important (5) and Don't know].
a. Complexity of the purchase
b. Uncertainty in identifying appropriate vendors
c. Higher level review processes
d. Environmental sustainability concerns

13. How influential are each of the following individuals or organizations in promoting environmental sustainability practices in your department? [Answer options: From Very influential (1) to Not influential (5) and Don't know].
a. Federal government
b. State government
c. Other city departments
d. City executive (manager or mayor)
e. City council
f. City employees
g. Citizens
h. Vendors
i. Business associations
j. Environmental groups or organizations

14. To what extent do you agree with the following statements as they relate to the sustainability policy in your department? [Answer options: From Strongly agree (1) to Strongly disagree (5) and Don't know].
a. Top managers are responsible for the implementation of environmental sustainability policies.
b. Mid-level managers are responsible for the implementation of environmental sustainability policies.
c. Staff employees are responsible for the implementation of environmental sustainability policies.

15. How important are the following concerns to your department? [Answer options: From Very important (1) to Not important (5) and Don't know]. 

a. Energy conservation
b. Water conservation
c. Solid waste reduction
d. Greenhouse gas emissions reductions
e. Recycling
f. Air pollution reductions (ozone, smog)
g. Biodiversity
h. Mobility
i. Urban planning and construction

16. Within your department, how important are environmental sustainability concerns to the purchase of the following types of products and services? [Answer options: From Very important (1) to Not important (5) and Don't know].
a. Chemical products
b. Road construction/maintenance services
c. General construction services
d. Electrical products
e. Information technology hardware and services
f. Professional services
g. Transportation/fuels
h. Wood and paper products

17. In your view, to what extent does each of the following either constrain or facilitate your department's ability to implement environmentally sustainable purchasing? [Answer options: From Strongly facilitates (1) to Strongly constrains (5) and Don't know]
a. Financial resources
b. Human resources
c. Employee attitudes
d. Law and regulation
e. Top Management
f. Availability information

18. How important or unimportant are the following considerations in your department's purchasing decisions? [Answer options: From Very important (1) to Not important (5) and Don't know].
a. Environmental sustainability of the products/services offered
b. Disposal costs
c. Reducing packaging waste
d. Life-cycle cost assessment
e. Recyclability or reuse
f. Reducing greenhouse gas impacts

19. In thinking about your relationships with vendors, to what extent do you disagree or agree with the following statements about procurement/purchasing in your department? [Answer options: From Strongly agree (1) to Strongly disagree (5) and Don't know].
a. It is easy to switch vendors in my department
b. Many of my department's vendors offer environmentally friendly products and services
c. Vendors closely monitor our department's procurement decisions 
d. Vendors often provide unreliable information about environmentally friendly products and services

e. Vendors help us learn about environmentally sustainable purchasing options

If $3=$ Yes, how would you assess your city's overall implementation of this policy? [Answer options: From Very unsuccessful (-5) to Very successful (5)].

20. To what extent do you disagree or agree with the following statements? [Answer options: From Strongly agree (1) to Strongly disagree (5) and Don't know].
a. My department has too many rules and procedures
b. Employees in my department are constantly being checked on for rule violations

21. How frequently do you interact with your: [Answer options: From Very frequently (1) to Very infrequently (5) and Don't know].
a. City's executive manager (e.g., mayor or city manager)
b. City's council members

22. To what extent do you disagree or agree with the following statements about your department? [Answer options: From Strongly agree (1) to Strongly disagree (5) and Don't know].
a. This department has a strong commitment to innovation
b. We reward employees who develop innovative solutions
c. This department is a dynamic and entrepreneurial place
d. Most employees in this department are not afraid to take risks

23. How would you assess your department's overall financial standing over the past five years? [Answer options: From Very strong (1) to Very weak (5) and Don't know].

24. What is the official title of your current position? [Open question].

25. How long have you worked for the city? [Answer options: number of years].

26. How long have you held your current position? [Answer options: number of years].

27. How many employees do you directly supervise? [Answer options: number of employees].

28. In a typical week, approximately how many hours do you spend on purchasing, procurement, or contracting activities? [Answer options: number of hours].

29. To what extent are you active in professional associations in your field? [Answer options: From Very active (1) to Not active (5) and Don't know].

30. What is your highest level of educational attainment? [Answer options: From Elementary school (1) to Post graduate (8)].

31. What best describes the field of study of your highest degree? (e.g., business, public administration, law, etc.) [Open question].

32. What is your gender? [Answer options: Male, Female]

33. What year were you born? [Answer options: years]

34. Are you a member of a historically underrepresented minority group? [Answer options: Yes, No, Don't know, Prefer not to answer]

35. In your personal time how frequently do you: [Answer options: From Very frequently (1) to Very infrequently (5) and Don't know]
a. Recycle solid waste at home
b. Conserve energy at home
c. Conserve water at home
d. Purchase environmentally friendly products
e. Compost food waste 
f. Donate either time or money to an environmental organization

36. Is there anything else that you would like to share about your city's or department's procurement activities? [Open question]

37. Which of the following initiatives do you know [Answer options: From I'm involved (1) to Don't know (5)]:
a. Sustainable Public Procurement. Public Function Secretary
b. Inter-American Government Procurement Network
c. Local Governments for Sustainability. Secretariat for Mexico, Latin America, and the Caribbean
d. Environmental Procurement Program of Mexico City
e. Marrakech Working Groups for sustainable purchases
f. Special Program for Sustainable Production and Consumption (PEPyCS), SEMARNAT
g. Global Network of Leading Cities in Sustainable Public Procurement

\section{Appendix B}

Table A1. LASSO procedure.

\begin{tabular}{|c|c|c|c|c|c|c|c|}
\hline Knot & ID & Lambda & $\mathbf{s}$ & L1-Norm & EBIC & Pseudo-R2 & Entered/Removed \\
\hline 1 & 1 & 32.62 & 0 & 0.91 & 288.63 & 0.00 & Added Constant \\
\hline 2 & 2 & 29.70 & 1 & 0.97 & 289.23 & 0.01 & Added Environmental Policies \\
\hline \multirow[t]{2}{*}{3} & 3 & 27.03 & 2 & 1.03 & 289.87 & 0.03 & Added Environmental practices \\
\hline & 4 & 24.61 & 2 & 1.08 & 286.81 & 0.04 & \\
\hline \multirow[t]{3}{*}{4} & 5 & 22.40 & 3 & 1.14 & 288.23 & 0.05 & Added Citywide contracting \\
\hline & 6 & 20.39 & 3 & 1.19 & 285.20 & 0.06 & \\
\hline & 7 & 18.56 & 3 & 1.24 & 282.69 & 0.07 & \\
\hline 5 & 8 & 16.90 & 5 & 1.31 & 288.87 & 0.07 & Added Staff Decision Locus \& Environmental concerns \\
\hline \multirow[t]{3}{*}{6} & 9 & 15.38 & 6 & 1.46 & 290.21 & 0.08 & Time for Routine Low-Cost Purchase \\
\hline & 10 & 14.00 & 6 & 1.63 & 286.82 & 0.10 & \\
\hline & 11 & 12.75 & 6 & 1.80 & 284.00 & 0.11 & \\
\hline 7 & 12 & 11.60 & 7 & 1.96 & 285.73 & 0.11 & Added Department Rules. \\
\hline 8 & 13 & 10.56 & 9 & 2.10 & 291.76 & 0.12 & Added Department resources and Population Logarithm \\
\hline \multirow[t]{5}{*}{9} & 14 & 9.61 & 11 & 2.05 & 297.69 & 0.13 & Added E-procurement System and Department Innovation \\
\hline & 15 & 8.75 & 11 & 2.00 & 295.40 & 0.14 & \\
\hline & 16 & 7.97 & 11 & 1.96 & 293.44 & 0.15 & \\
\hline & 17 & 7.25 & 11 & 1.93 & 291.76 & 0.15 & \\
\hline & 18 & 6.60 & 11 & 2.03 & 290.31 & 0.16 & \\
\hline \multirow[t]{2}{*}{10} & 19 & 6.01 & 12 & 2.39 & 292.71 & 0.16 & Added Financial Strength \\
\hline & 20 & 5.47 & 12 & 2.72 & 291.09 & 0.17 & \\
\hline \multirow[t]{2}{*}{11} & 21 & 4.98 & 13 & 3.04 & 293.97 & 0.17 & Added Purchase Characteristics. \\
\hline & 22 & 4.53 & 13 & 3.33 & 292.75 & 0.18 & \\
\hline 12 & 23 & 4.13 & 14 & 3.60 & 296.00 & 0.18 & Added Time for Technical High-Cost Purchase \\
\hline 13 & 24 & 3.76 & 15 & 3.88 & 299.34 & 0.19 & Added Environmental Program Knowledge \\
\hline 14 & 25 & 3.42 & 17 & 4.18 & 306.86 & 0.19 & Added Mid-Level Decision Locus and Leader Involvement. \\
\hline \multirow[t]{2}{*}{15} & 26 & 3.11 & 18 & 4.48 & 310.17 & 0.19 & Added Department Purchase Concern \\
\hline & 27 & 2.83 & 18 & 4.77 & 309.33 & 0.20 & \\
\hline \multirow[t]{2}{*}{16} & 28 & 2.58 & 20 & 5.31 & 317.11 & 0.20 & $\begin{array}{l}\text { Added Time for technical high cost purchase and \% } \\
\text { Population with higher education }\end{array}$ \\
\hline & 29 & 2.35 & 20 & 6.01 & 316.36 & 0.20 & \\
\hline \multirow[t]{3}{*}{17} & 30 & 2.14 & 21 & 6.65 & 319.99 & 0.20 & Added Top management decision locus \\
\hline & 31 & 1.95 & 21 & 7.24 & 319.42 & 0.21 & \\
\hline & 32 & 1.77 & 21 & 7.78 & 318.94 & 0.21 & \\
\hline \multirow[t]{5}{*}{18} & 33 & 1.61 & 22 & 8.29 & 322.82 & 0.21 & Added Stakeholder influence \\
\hline & 34 & 1.47 & 22 & 8.77 & 322.43 & 0.21 & \\
\hline & 35 & 1.34 & 22 & 9.21 & 322.09 & 0.21 & \\
\hline & 36 & 1.22 & 22 & 9.62 & 321.81 & 0.21 & \\
\hline & 37 & 1.11 & 22 & 9.99 & 321.58 & 0.21 & \\
\hline & 38 & 1.01 & 23 & 10.34 & 325.67 & 0.21 & Added Department Environmental Concern \\
\hline \multirow[t]{5}{*}{20} & 39 & 0.92 & 24 & 10.67 & 329.77 & 0.21 & Added Information availability \\
\hline & 40 & 0.83 & 24 & 11.00 & 329.60 & 0.21 & \\
\hline & 41 & 0.76 & 24 & 11.30 & 329.45 & 0.22 & \\
\hline & 42 & 0.69 & 24 & 11.58 & 329.33 & 0.22 & \\
\hline & 43 & 0.63 & 24 & 11.83 & 329.23 & 0.22 & \\
\hline
\end{tabular}


Table A1. Cont.

\begin{tabular}{cccccccc}
\hline Knot & ID & Lambda & s & L1-Norm & EBIC & Pseudo-R2 & Entered/Removed \\
\hline \multirow{2}{2}{20} & 44 & 0.57 & 24 & 12.07 & 329.14 & 0.22 \\
& 45 & 0.52 & 24 & 12.28 & 329.07 & 0.22 & \\
& 46 & 0.48 & 24 & 12.48 & 329.01 & 0.22 \\
& 47 & 0.43 & 24 & 12.66 & 328.96 & 0.22 \\
\\
48 & 0.39 & 24 & 12.82 & 328.92 & 0.22 \\
\\
49 & 0.36 & 24 & 12.97 & 328.89 & 0.22 & \\
& 50 & 0.33 & 24 & 13.11 & 328.86 & 0.22 & \\
\hline
\end{tabular}

Obtaining solution for 50 lambdas.

\section{References}

1. Appolloni, A.; Sun, H.; Jia, F.; Li, X. Green Procurement in the private sector: A state of the art review between 1996 and 2013. J. Clean. Prod. 2014, 85, 122-133. [CrossRef]

2. Appolloni, A.; D'Amato, A.; Cheng, W. Is public procurement going green? Experiences and open issues. Exp. Open Issues 2011, 1-30. [CrossRef]

3. Brammer, S.; Walker, H. Sustainable procurement in the public sector: An international comparative study. Int. J. Oper. Prod. Manag. 2011, 31, 452-476. [CrossRef]

4. Preuss, L. Addressing sustainable development through public procurement: The case of local government. Supply Chain Manag. Int. J. 2009, 14, 213-223. [CrossRef]

5. Appolloni, A.; Coppola, M.A.; Piga, G. Implementation of Green Considerations in Public Procurement: A Means to Promote Sustainable Development. In Green Public Procurement Strategies for Environmental Sustainability; IGI GLOBAL: Hershey, PA, USA, 2019; pp. 23-44.

6. Darnall, N.; Stritch, J.M.; Bretschneider, S.; Hsueh, L.; Duscha, M.; Iles, J.; No, W.; Suarez, J.; Burwell, C. Advancing Green Purchasing in Local Governments; Arizona State University: Phoenix, AZ, USA, 2017.

7. Hawkins, C.V.; Kwon, S.-W.; Bae, J. Balance Between local economic development and environmental sustainability: A multi-level governance perspective. Int. J. Public Adm. 2016, 39, 803-811. [CrossRef]

8. Krause, R.M. Policy Innovation, intergovernmental relations, and the adoption of climate protection initiatives by U.S. Cities. J. Urban Aff. 2011, 33, 45-60. [CrossRef]

9. Cheng, W.; Appolloni, A.; D'Amato, A.; Zhu, Q. Green Public procurement, missing concepts and future trends-A critical review. J. Clean. Prod. 2018, 176, 770-784. [CrossRef]

10. Simcoe, T.; Toffel, M.W. Government green procurement spillovers: Evidence from municipal building policies in California. J. Environ. Econ. Manag. 2014, 68, 411-434. [CrossRef]

11. Nijaki, L.K.; Worrel, G. Procurement for sustainable local economic development. Int. J. Public Sect. Manag. 2012, 25, 133-153. [CrossRef]

12. Tukker, A.; Emmert, S.; Charter, M.; Vezzoli, C.; Sto, E.; Munch Andersen, M.; Geerken, T.; Tischner, U.; Lahlou, S. Fostering change to sustainable consumption and production: An evidence based view. J. Clean. Prod. 2008, 16, 1218-1225. [CrossRef]

13. Sanchez, A.X.; Lehtiranta, L.; Hampson, K.; Kenley, R. Evaluation framework for green procurement in road construction. Smart Sustain. Built Environ. 2014, 3, 153-169. [CrossRef]

14. Secretaría de Hacienda. Política de Gasto del Ejecutivo Federal; Gobierno de México: Mexico City, Mexico, 2020.

15. Da Costa, B.B.F.; Da Motta, A.L.T.S. Key factors hindering sustainable procurement in the Brazilian Public sector: A Delphi study. Int. J. Sustain. Dev. Plan. 2019, 14, 152-171. [CrossRef]

16. Secretaria de Medio Ambiente y Recursos Naturales (SEMARNAT). Manual de Sistemas de Manejo Ambiental; Gobierno de México: Mexico City, Mexico, 2010.

17. Studer, I.; Contreras, T. Compras Públicas Sustentables en México; The German Corporation for International Cooperation: Mexico City, Mexico, 2016.

18. Secretaría del Medio Ambiente. Publica Sedema Lineamientos de Compras Verdes Para la Administración Pública de la CDMX. Available online: https://sedema.cdmx.gob.mx/comunicacion/nota/publica-sedemalineamientos-de-compras-verdes-para-la-administracion-publica-de-la-cdmx (accessed on 4 July 2020).

19. GIZ. Elaboración de Propuestas para Fomentar las Compras Públicas Sustentables en Tres Municipios Mexicanos; The German Corporation for International Cooperation: Mexico City, Mexico, 2017. 
20. Raj, A.; Agrahari, A.; Srivastava, S.K. Do pressures foster sustainable public procurement? An empirical investigation comparing developed and developing economies. J. Clean. Prod. 2020, 266, 122055. [CrossRef]

21. Presidencia de la República. Primer Informe de Gobierno 2018-2019; Gobierno de México: Mexico City, Mexico, 2019.

22. Darnall, N.; Stritch, J.M.; Bretschneider, S.; Hsueh, L. Local Government Green Purchasing Survey; Arizona State University: Phoenix, AZ, USA, 2017.

23. Sönnichsen, S.D.; Clement, J. Review of green and sustainable public procurement: Towards circular public procurement. J. Clean. Prod. 2020, 245. [CrossRef]

24. Tibshirani, R. Regression Shrinkage and Selection Via the Lasso. J. R. Stat. Soc. Ser. B Stat. Methodol. 1996, 58, 267-288. [CrossRef]

25. Nadeem, S.; Mohamad, M.H.B.; Abdullah, N.A.H.B.N. Sustainable procurement behavior: A case of government departments. Int. J. Econ. Perspect. 2017, 11, 402-416.

26. Kozik, R.; Karasiska-Jakowiec, I. Green public procurement-legal base and instruments supporting sustainable development in the construction industry in Poland. E3S Web Conf. 2016, 10. [CrossRef]

27. Erdmenger, C. Buying into the Environment: Experiences, opportunities and potential for eco-procurement. Int. J. Sustain. High. Educ. 2003, 4. [CrossRef]

28. Lavey, W.G. Buying into securities filings. Environ. Forum 2016, 33, 25-26.

29. DEFRA. Procuring the Future: SP National Action Plan: Recommendations from the SP Task Force; DEFRA: London, UK, 2006.

30. Lindström, H.; Lundberg, S.; Marklund, P.O. How Green Public Procurement can drive conversion of farmland: An empirical analysis of an organic food policy. Ecol. Econ. 2020, 172, 106622. [CrossRef]

31. Coggburn, J.D.; Rahm, D. Environmentally preferable purchasing: Who is doing what in the united states? J. Public Procure. 2005, 5, 23-53. [CrossRef]

32. EU Commission. Public Procurement for a Circular Economy: Good Practice and Guidance; European Commission: Brussels, Belgium, 2017.

33. Bolton, P. Protecting the environment through public procurement: The case of South Africa. Nat. Resour. Forum 2008, 32, 1-10. [CrossRef]

34. Stoffel, T.; Cravero, C.; La Chimia, A.; Quinot, G. Multidimensionality of sustainable public procurement (SPP)—Exploring concepts and effects in Sub-Saharan Africa and Europe. Sustainability 2019, 11, 6352. [CrossRef]

35. Adjei-Bamfo, P.; Maloreh-Nyamekye, T. The "baby steps" in mainstreaming sustainable public procurement in Ghana: A “double-agency" perspective. J. Public Aff. 2019, 19, e1902. [CrossRef]

36. Panda, P.; Sahu, G.P. Fulfilling Public Procurement Expectations in India: Need of legislative Intervention. In Proceedings of the 7th International Conference on Theory and Practice of Electronic Governance, Seoul, Korea, 22-25 October 2013; pp. 103-111. [CrossRef]

37. Zaidi, S.A.H.; Mirza, F.M.; Hou, F.; Ashraf, R.U. Addressing the sustainable development through sustainable procurement: What factors resist the implementation of sustainable procurement in Pakistan? Socioecon. Plan. Sci. 2019, 68, 1. [CrossRef]

38. Shai, L.; Molefinyana, C.; Quinot, G. Public Procurement in the context of broad-based black economic empowerment (BBBEE) in South Africa-Lessons Learned for sustainable public procurement. Sustainability 2019, 11, 7164. [CrossRef]

39. Kasemsap, K. Mastering Electronic Procurement, Green Public Procurement, and Public Procurement for Innovation. In Digital Governance E-Government Principles Applied to Public Procurement; IGI Global: Hershey, PA, USA, 2017; pp. 29-55. [CrossRef]

40. Ho, L.W.P.; Dickinson, N.M.; Chan, G.Y.S. Green procurement in the asian public sector and the Hong Kong private sector. Nat. Resour. Forum 2010, 34, 24-38. [CrossRef]

41. Liu, J.; Shi, B.; Xue, J.; Wang, Q. Improving the green public procurement performance of Chinese local governments: From the perspective of officials' knowledge. J. Purch. Supply Manag. 2019, 25, 100501. [CrossRef]

42. Liu, J.; Xue, J.; Yang, L.; Shi, B. Enhancing green public procurement practices in local governments: Chinese evidence based on a new research framework. J. Clean. Prod. 2019, 211, 842-854. [CrossRef]

43. Schwerin, E.; Prier, E. Research article: Rent-seeking obstacles to changing environmental practices and sustainable public procurement in China. Environ. Pract. 2013, 15, 240-252. [CrossRef] 
44. Tian, F. Green Public Procurement in China: Current Practices, Barries and Opportunities. In Proceedings of the International Conference on Management and Service Science MASS 2010, Wuhan, China, 24-26 August 2010. [CrossRef]

45. Wang, C.; Qiao, Y.; Li, X. A systems approach for green public procurement implementation. J. Public Procure 2020, 20, 287-311. [CrossRef]

46. Wang, Q.; Zhang, R.; Liu, J. Price/time/intellectual efficiency of procurement: Uncovering the related factors in Chinese public authorities. J. Purch. Supply Manag. 2020, 100622. [CrossRef]

47. Zhu, Q.; Geng, Y.; Sarkis, J. Motivating green public procurement in China: An individual level perspective. J. Environ. Manag. 2013, 126, 85-95. [CrossRef]

48. Adebayo, V.O. Examining the Implantation of Sustainability Into State Procurement Decision Models: An Experiential Overview of the Nigerian Public Sector. In Proceedings of the World Congress on Sustainable Technologies WCST 2015, London, UK, 14-16 December 2015; pp. 71-76. [CrossRef]

49. Akenroye, T.O.; Oyegoke, A.S.; Eyo, A.B. Development of a framework for the implementation of green public procurement in Nigeria. Int. J. Procure. Manag. 2013, 6, 1-23. [CrossRef]

50. Davies, I.E.E.; Nwankwo, C.O.; Olofinnade, O.M.; Michaels, T.A. Insight review on impact of infrastructural development in driving the SDGs in developing nations: A case study of Nigeria. IOP Conf. Ser. Mater. Sci. Eng. 2019, 640. [CrossRef]

51. Kleine, D.; Das, G.B.M. Repoliticising and scaling-up ethical consumption: Lessons from public procurement for school meals in Brazil. Geoforum 2015, 67, 135-147. [CrossRef]

52. Couto, H.L.G.D.; Ribeiro, F.L. Objetivos e desafios da política de compras públicas sustentáveis no Brasil: A opinião dos especialistas. Rev. Adm. Pública 2016, 50, 331-343. [CrossRef]

53. Delmonico, D.; Jabbour, C.J.C.; Pereira, S.C.F.; de Sousa Jabbour, A.B.L.; Renwick, D.W.S.; Thomé, A.M.T. Unveiling barriers to sustainable public procurement in emerging economies: Evidence from a leading sustainable supply chain initiative in Latin America. Resour. Conserv. Recycl. 2018, 134, 70-79. [CrossRef]

54. Novaes das Virgens, T.A.; Andrade, J.C.S.; Hidalgo, S.L. Carbon footprint of public agencies: The case of Brazilian prosecution service. J. Clean. Prod. 2020, 251. [CrossRef]

55. Jaafar, M.R.; Aziz, S.A.; Ramli, N.M. The roles of compliance with government procurement policy: Moderating the effects between explanatory factors and sustainable public procurement practice. J. Pengur. 2016, 48, 89-98. [CrossRef]

56. Wang, C.; Ghadimi, P.; Lim, M.K.; Tseng, M.L. A literature review of sustainable consumption and production: A comparative analysis in developed and developing economies. J. Clean. Prod. 2019, 206, 741-754. [CrossRef]

57. Adjei-Bamfo, P.; Maloreh-Nyamekye, T.; Ahenkan, A. The role of e-government in sustainable public procurement in developing countries: A systematic literature review. Resour. Conserv. Recycl. 2019, 142, 189-203. [CrossRef]

58. Pichardo Pagaza, I. Responsabilidades municipales en materia ambiental. Convergencia 2009, 16, $291-308$.

59. INEGI. Population and Housing Census 1990-2010. Available online: http://www.inegi.org.mx/est/con\% 0Atenidos/Proyectos/ccpv/cpvsh/Series_historicas.aspx (accessed on 15 March 2020).

60. Aguirre-Urreta, M.I.; Hu, J. Detecting common method bias: Performance of the Harman's single-factor test. ACM SIGMIS DATABASE Adv. Inf. Syst. 2019, 50, 45-70. [CrossRef]

61. Podsakoff, P.M.; Organ, D.W. Self-reports in organizational research: Problems and prospects. J. Manag. 1986, 12, 531-544. [CrossRef]

62. Armstrong, J.S.; Overton, T.S. Estimating nonresponse bias in mail surveys. J. Mark. Res. 1977, 14, $396-402$. [CrossRef]

63. Darnall, N.; Arimura, T.; Miyomoto, T.; Stritch, J.M.; Bretschneider, S.; Hsueh, L. Advancing Green Purchasing in Japanese Municipalities; Arizona State University: Phoenix, AZ, USA, 2018.

64. Abdi, H.; Béra, M. Correspondence Analysis. In Encyclopedia of Social Network Analysis and Mining; Springer: New York, NY, USA, 2014; pp. 275-284.

65. Cronbach, L.J. Coefficient alpha and the internal structure of tests. Psychometrika 1951, 16, 297-334. [CrossRef]

66. Huang, C.-C.; Wang, Y.-M.; Wu, T.-W.; Wang, P.-A. An empirical analysis of the antecedents and performance consequences of using the moodle platform. Int. J. Inf. Educ. Technol. 2013, 217-221. [CrossRef]

67. Fornell, C.; Larcker, D.F. Evaluating structural equation models with unobservable variables and measurement error. J. Mark. Res. 2006, 18, 39. [CrossRef] 
68. Tibshirani, R.; Bien, J.; Friedman, J.; Hastie, T.; Simon, N.; Taylor, J.; Tibshirani, R.J. Strong rules for discarding predictors in lasso-type problems. J. R. Stat. Soc. Ser. B Stat. Methodol. 2012, 74, 245-266. [CrossRef]

69. Friedman, J.; Hastie, T.; Tibshirani, R. Regularization paths for generalized linear models via coordinate descent. J. Stat. Softw. 2010, 33, 1-22. [CrossRef] [PubMed]

70. Lăzăroiu, G.; Ionescu, L.; Uţă, C.; Hurloiu, I.; Andronie, M.; Dijmarescu, I. Environmentally responsible behavior and sustainability policy adoption in green public procurement. Sustainability 2020, 12, 2110. [CrossRef]

71. Adler, P.S.; Borys, B. Two types of bureaucracy: Enabling and coercive. Adm. Sci. Q. 1996, 41, 61. [CrossRef]

72. Olsen, J.P. Maybe It is time to rediscover bureaucracy. J. Public Adm. Res. Theory 2006, 16, 1-24. [CrossRef]

73. Secretaría de la Función Pública. Contrataciones Públicas Sustentables. Available online: https://www.gob. $\mathrm{mx} / \mathrm{sfp} /$ acciones-y-programas/contrataciones-publicas-sustentables (accessed on 4 July 2020).

74. Gobierno de la República. Programa Especial de Producción y Consumo Sustentable (PEP y CS) 2014-2018; Gobierno de México: Mexico City, Mexico, 2014.

75. Cámara de Diputados del, H. Congreso de la Unión. In Ley General de Cambio Climático; Gobierno de México: Mexico City, Mexico, 2018. Available online: http://www.diputados.gob.mx/LeyesBiblio/pdf/LGCC_130718. pdf (accessed on 4 July 2020).

76. RICG. Red Interamericana de Compras Gubernamentales. Available online: http://ricg.org/ (accessed on 4 July 2020).

77. ICLEI. Secretariado para México Centroamérica y Caribe. Available online: https://iclei.org.mx/contenidos. php?id=2 (accessed on 4 July 2020).

78. Palacios, M.Á.S. Hacia la implementación de patrones de sostenibilidad ambiental en la producción y consumo: Compras públicas sostenibles. Rev. Derecho Soc. 2014, 42, 201-212.

79. GLCN. Global Lead City Network on Sustainable Procurement. Available online: https://glcn-on-sp.org/ home/ (accessed on 4 July 2020).

(C) 2020 by the authors. Licensee MDPI, Basel, Switzerland. This article is an open access article distributed under the terms and conditions of the Creative Commons Attribution (CC BY) license (http://creativecommons.org/licenses/by/4.0/). 